\title{
CD 154: STRONG GLUTEN WHEAT WITH HIGH YIELD POTENTIAL
}

\author{
CD 154: TRIGO MELHORADOR E DE ALTO POTENCIAL PRODUTIVO
}

\author{
Volmir Sergio MARCHIORO ${ }^{1}$; Francisco de Assis FRANCO ${ }^{1}$; Ivan SCHUSTER ${ }^{1}$; \\ Tatiane DALLA NORA ${ }^{1}$; Fábio Junior Alcântara de LIMA²; Adriel EVANGELISTA ${ }^{2}$; \\ Mateus POLO ${ }^{2}$ \\ 1. Pesquisador(a), Doutor(a), COODETEC, BR 467, Cascavel, PR, Brasil. volmir@ coodetec.com.br; \\ 2. Engenheiro Agrônomo, COODETEC, Cascavel, PR, Brasil.
}

\begin{abstract}
Wheat breeding programs focus on potential grain yield, industrial quality, low plant height, and disease resistance. Cultivar CD 154 was a result of the search for cultivars with high yield potential and industrial wheat quality. This cultivar was derived from a cross between CD 104 and CDI 200104, by COODETEC, in 1999. Cultivar CD 154 was included in preliminary grain yield trials in 2005 and 2006, and was then tested to determine the Value of Cultivation and Use (VCU) from 2007 to 2012, with the acronym CD 0705. All trials were arranged in an experimental design of randomized blocks with three replications. The yield of cultivar CD 154 was $16 \%, 10 \%$ and $4 \%$ higher than the mean yield of the two best controls, respectively, in the wheat-growing regions VCU 2, 3 and 4. The analysis of industrial quality, resulted in a mean gluten strength of 364 and mean stability of $17.1 \mathrm{~min}$, which allows the inclusion cultivar CD 154 in the cultivar group of strong gluten wheat. The cultivar is classified as strong gluten wheat, has a high yield potential and good lodging resistance, and is therefore another promising alternative for wheat farmers of the hottest regions of Brazil.
\end{abstract}

KEYWORDS: Triticum aestivum L. Breeding wheat. Lodging.

Wheat breeding programs focus on potential grain yield, industrial quality, low plant height, and disease resistance (BRUNETTA E DOTTO, 2000) and many have made significant progress in grain yield and other relevant traits (KOHLI, 1998), among them processing quality.

The wheat flour quality is determined by the genetics of the cultivar, varying according to the growth environment. The genetic of a cultivar defines the potential and balance of the proteins, especially those of gluten, which, according to BRAMMER (2000), are present in the grain endosperm, and account for $85 \%$ of the proteins in the flour and are mainly responsible for the wheat quality. Cultivar CD 154 was a result of the search for cultivars with high yield

Cultivar CD 154 was derived from a cross between wheat cultivars CD 104 and CDI 200104, by COODETEC, in 1999, in Palotina. The F1 seeds were sown in 1999 in a greenhouse in Cascavel. At maturity all ears were bulk-harvested and later threshed, providing F2 seeds. The F2 population was selected in 2000, in Cascavel, by the mass method. The populations F3 to F5 were selected by the pedigree method in Palotina. Each plant of the plot was harvested and threshed separately, resulting in various populations, derived from each plant of this cross. The characteristics were fixed in the F6 generation, resulting in multiple rows, one of which originated $\mathrm{CD} 154$. The pedigree of this line is CC15154-0T-1P-2P-2P-0P.
Cultivar CD 154 was included in preliminary grain yield tests in 2005 and 2006, carried out in Cascavel and Palotina due to its superior performance than of the controls evaluated in trials to determine the Value of Cultivation and Use (VCU), in 2007, 2008, 2009, 2010, 2011, and 2012 with the initials CD 0705 . The VCU tests were carried out in the specific wheat-growing regions (EMBRAPA TRIGO, 2006).

VCU trials in the wheat Region 2 were conducted in Campo Mourão/PR (two growing seasons), Cascavel/PR (three seasons) and Taquarivaí/SP, in 2008; in Campo Mourão/PR (two seasons) and Cascavel/PR (three seasons), in 2009; in Campo Mourão/PR (two seasons), Cascavel/PR (three seasons) and Itaberá/SP, in 2010; in Campo Mourão/PR (two seasons) and Cascavel/PR (two seasons), in 2011; and in Campo Mourão/PR (two seasons), Cascavel/PR (three seasons), and Itaberá/SP in 2012.

In the wheat region 2, VCU trials assays were carried out in Arapongas/PR, Palotina/PR (four growing seasons) and Palmital/SP, in 2008; in Arapongas/PR, Goioerê/PR, Palotina/PR (four seasons), Dourados/MS (two seasons), Maracaju/MS, Ponta Porã/MS and Palmital/SP, in 2009; Arapongas/PR, Goioerê/PR, Palotina/PR (four seasons), Dourados/MS (two seasons), Ponta Porã/MS and Palmital/SP, in 2010; in Palotina/PR (three seasons), in 2011; and in Arapongas/PR, 
Palotina/PR (four seasons), Dourados/MS (two seasons), Manduri/SP, in 2012.

The VCU trials in the wheat region 4 were conducted in Cristalina/GO and São Gotardo/MG, in 2008; in Catalão/GO, Luziânia/GO, Paracatu/MG and São Gotardo/MG, in 2009; and in Catalão/GO, Luziânia/GO, Paracatu/MG and São Gotardo/MG, in 2010, resulting in a total of 79 trials of all wheatgrowing regions.

The experiment was arranged in a randomized block design with three replications in plots consisting of six 5-m long rows, spaced $0.20 \mathrm{~m}$ apart, with mechanical sowing. Fertilization and pest and disease control were applied according to technical recommendations (REUNIÃO 2008). Prior to sowing, the seeds were treated with Triadimenol + Imidacloprid.

The measured values were grain yield, days from emergence to heading, days from emergence to maturity, plant height, lodging, test weight, 1000grain weight, and gluten strength. At strategic locations, collections of genotypes were grown representing the VCU trials, to which no disease control of the aerial part was applied, where diseases such as leaf rust, leaf spot, powdery mildew, head blight, and blast, among others were observed.

Table 1 shows the mean grain yield in the wheat-growing regions $\mathrm{VCU} 2,3$ and 4, respectively, where cultivar CD 154 produced yields $16 \%, 10 \%$ and $4 \%$ higher than the mean of the two controls, in the three wheat-growing regions. Due to its excellent performance, cultivar CD 154 was indicated for cultivation in the regions mentioned above, i.e., in the states of Paraná, Mato Grosso do Sul, São Paulo, Goiás, and Minas Gerais (BRASIL, 2010).

The plant height of cultivar CD 154 is low to medium, with an average height of $75 \mathrm{~cm}$, ranging from 68 to $90 \mathrm{~cm}$. The cycle length is medium, lasting from 55 to 80 days from emergence to heading and from 99 to 132 days from emergence to maturity. The means of these characteristics were 66 and 116 days, respectively, which vary according to the climatic conditions, sowing date and soil type.

CD 154 has fusiform ears, is moderately resistant to lodging and moderately susceptible to pre-harvest sprouting. In terms of quality, this cultivar had a mean test weight of $78 \mathrm{~kg} \mathrm{hl}^{-1}$ and a mean 1000-grain weight of 37 grams. The analysis of industrial quality, based on 35 experimental samples from the different states, resulted in a mean gluten strength of 364 and mean stability of 17.1 min, which allows the inclusion in the cultivar group of strong gluten wheat, available on the market similarly to CD 150 and CD 151 (FRANCO et al., 2008; FRANCO et al., 2009).

Table 1. Mean grain yield $\left(\mathrm{kg} \mathrm{ha}^{-1}\right)$ of cultivar CD 154 and the two best controls, tests VCU VCU conducted in Regions 2, 3 and 4 of the states of Paraná, São Paulo, Mato Grosso do Sul, Goiás and Minas Gerais, from 2008 to 2012-Cascavel/2014.

\begin{tabular}{|c|c|c|c|c|c|c|c|c|c|c|c|c|}
\hline \multirow{2}{*}{ Cultivar } & \multicolumn{2}{|c|}{2008} & \multicolumn{2}{|c|}{2009} & \multicolumn{2}{|c|}{2010} & \multicolumn{2}{|c|}{2011} & \multicolumn{2}{|c|}{2012} & \multicolumn{2}{|c|}{ Overall } \\
\hline & Mean & $\%$ & Mean & $\%$ & Mean & $\%$ & Mean & $\%$ & Mean & $\%$ & Mean & $\%$ \\
\hline & \multicolumn{12}{|c|}{ 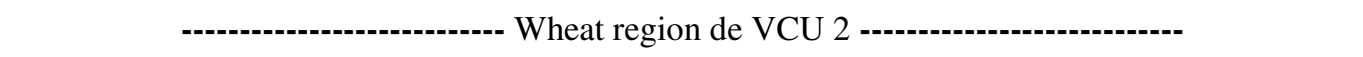 } \\
\hline CD 154 & 3978 & 116 & 2973 & 120 & 4933 & 116 & 3635 & 126 & 3937 & 102 & 3870 & 116 \\
\hline \multirow[t]{2}{*}{ Mean Test.* } & 3421 & 100 & 2474 & 100 & 4235 & 100 & 2891 & 100 & 3858 & 100 & 3376 & 100 \\
\hline & \multicolumn{12}{|c|}{ 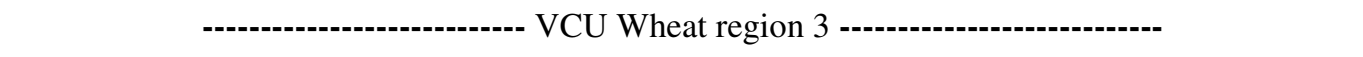 } \\
\hline CD 154 & 3407 & 102 & 3136 & 102 & 2978 & 117 & 3562 & 115 & 2645 & 112 & 3080 & 110 \\
\hline Mean Test.* & 3325 & 100 & 3070 & 100 & 2555 & 100 & 3088 & 100 & 2362 & 100 & 2880 & 100 \\
\hline & \multicolumn{12}{|c|}{ 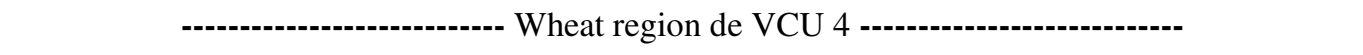 } \\
\hline CD 154 & 4817 & 106 & 4878 & 104 & 5124 & 101 & - & - & 5493 & 105 & 5165 & 104 \\
\hline Mean Test.* & 4526 & 100 & 4673 & 100 & 5075 & 100 & - & - & 5226 & 100 & 4875 & 100 \\
\hline
\end{tabular}

*In the wheat-growing regions VCU 2 and 3, the mean of the controls was composed of the mean of BRS 208 and IPR 85 in 2008 and 2009, with the cultivars BRS 220 and IPR 85 in 2010 and with the cultivars BRS GUAMIRIM and BRS PARDELA in 2011 and 2012. In the wheat-growing region VCU 4, the mean of the controls was composed of the mean of BRS 207 and BRS 210 in 2008 and of BRS 207 and BRS 264 in 2009, 2010 and 2012. 
In the field experiments, from 2007 to 2012, data of different diseases occurring in Brazil were recorded. The severity of powdery mildew (Erysiphe graminis tritici) was classified as average, corresponding to the characterization of moderately susceptible. For head blight (Fusarium graminearum), high scores were recorded, indicating that the cultivar is susceptible. To helmintosporiose (Bipolaris sorokiniana) and glume blotch (Septoria tritici and Stagonospora nodorum) indices of average severity of leaf spot and glume spot were determined that ranked the cultivar as moderately susceptible. The severity of leaf rust (Puccinia recondita f. sp. tritici) was average under field conditions, indicating that the cultivar is moderately susceptible. To blast (Pyricularia grisea (Cooke) Sacc.), CD 154 was classified as susceptible.

In view of the strong gluten wheat, high potential yield, lodging resistance, CD 154 is one more important alternative as cultivar for wheat farmers of the hottest regions of Brazil.

RESUMO: Os programas de melhoramento de trigo estão direcionados para potencial de rendimento de grãos, qualidade industrial, baixa estatura de planta e resistência às doenças. Buscando cultivares de potencial produtivo e qualidade industrial foi desenvolvida a cultivar de trigo CD 154. Está cultivar, foi obtida do cruzamento entre as cultivares CD 104 e CDI 200104, pela COODETEC, em 1999. A cultivar CD 154, participou dos Ensaios Preliminares de rendimento de grãos em 2005 e 2006, sendo em seguida testada em Ensaios de Determinação de Valor e Uso (VCU), nos anos de 2007 a 2012, com a sigla CD 0705. Todos os ensaios foram conduzidos em delineamento experimental de blocos ao acaso, com três repetições. A cultivar CD 154 apresentou um rendimento $16 \%, 10 \%$ e 4\% superior à média das duas melhores testemunhas, respectivamente, nas Regiões Tritícolas de VCU 2, 3 e 4. Os resultados de análise de qualidade industrial geraram uma média 364 de força geral de glúten e uma estabilidade média de 17,1 minutos, o que permite incluir a cultivar CD 154 no grupo de cultivares de trigo melhorador. A referida cultivar possui qualidade trigo melhorador, alto potencial de rendimento de grãos, boa resistência ao acamamento, sendo assim mais uma opção importante aos triticultores das Regiões mais quentes do Brasil.

PALAVRAS-CHAVE: Triticum aestivum L.: Melhoramento de trigo. Acamamento.

\section{REFERENCES}

BRUNETTA, D.; DOTTO, S. R. Trigo no Paraná: visão histórica, situação atual e perspectivas. In: Cunha GR. Trigo no Brasil Rumo ao Século XXI. Embrapa Trigo, Passo Fundo, p. 129-135, 2000.

BRAMMER, S. P. Marcadores moleculares: princípios básicos e uso em programas de melhoramento genético vegetal. Passo Fundo: Embrapa Trigo (Documento online n. 3), 2000. 12p.

BRASIL. Serviço nacional de proteção de cultivares. Brasília: Ministério da Agricultura. Disponível em http://www.agricultura.gov.br/sarc/dfpv/lst1200.htm. Acesso em 07 mai. 2010.

\section{REUNIÃO DA COMISSÃO BRASILEIRA DE PESQUISA DE TRIGO E TRITICALE. Informações técnicas para a safra 2008: Trigo e Triticale. Londrina: Embrapa Soja, (Documento, 301), 2010. 147p.}

EMBRAPA TRIGO. Regiões de adaptação para trigo no Brasil. Passo Fundo: Embrapa Trigo (Circular Técnica, 20), 2006. 35p.

FRANCO, A. F.; MARCHIORO, V. S.; DALLA NORA, T.; OLIVEIRA, E. F.; SCHUSTER, I.; VIEIRA, E. S. N.; SOBRINHO, A. A.; EVANGELISTA, A. CD 150 - short wheat cultivar with high quality and high yield. Crop Breeding and Applied Biotechnology, Viçosa, v. 8, p. 255-258, 2008.

FRANCO, A. F.; MARCHIORO, V. S.; DALLA NORA, T.; SCHUSTER, I.; EVANGELISTA, A.; LIMA, F. J. A. CD 151: cultivar de trigo de ampla adaptação. Bioscience Journal, Uberlândia, v. 29, n. 1, p. 101-103, 2013.

KOHLI, M. M. Use of biotechnology in wheat breeding in the southern cone region. In: KOHLI, M. M.; FRANCIS, M. Application of biotechnologies to wheat breeding. Uruguai: Colônia. p. 1-15, 1998. 